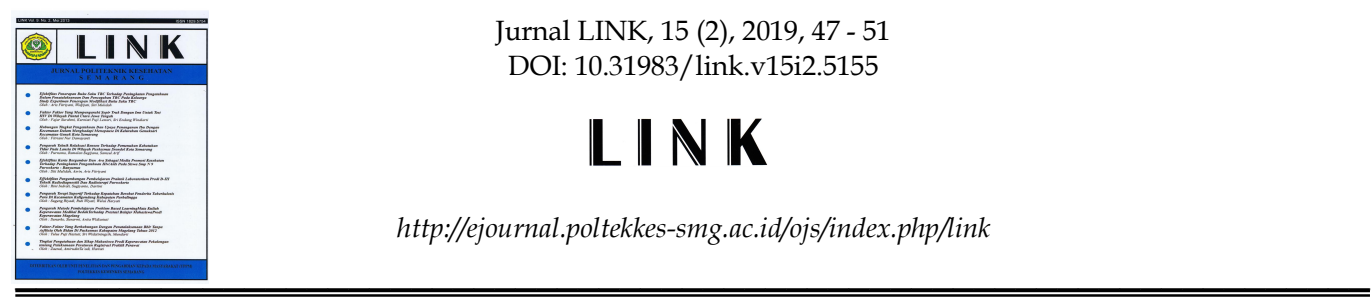

\title{
PROGRAM KUMPULAN WANITA MENOPAUSE AKTIF OLEH KADER DESA SUMBERBENDO KECAMATAN PARE
}

\author{
Reni Yuli Astutik $\left.{ }^{*}\right)$, , Mirthasari Palupi \\ 1)STIKES Karya Husada Kediri ; Akademi Gizi Karya Husada Kediri \\ Jl. Soekarno Hatta No. 7 Pare ; Kediri ; Jawa Timur
}

\begin{abstract}
Abstrak
Kader kesehatan merupakan perpanjangan tangan dari bidan yang berfungsi sebagai penggerak, motivator serta pemberi informasi kepada masyarakat, termasuk dalam peningkatan kualitas hidup wanita menopause. Di desa Sumberbendo Kecamatan Pare Kabupaten Kediri peran kader belum dapat dilaksanakan secara maksimal, hal ini dikarenakan kader belum pernah mendapatkan pelatihan tentang peran kader serta kurangnya informasi tentang menopause. Dalam rangka memenuhi salah satu tridharma perguruan tinggi yaitu pengabdian kepada masyarakat, maka dosen perlu berperan dalam meningkatkan kualitas hidup wanita menopause. Salah satu upaya yang dapat dilakukan yaitu dengan menggerakkan kader sehingga mampu menjalankan program Kumpulan Wanita Menopause Aktif (KUWAT) yang dapat diterapkan pada wanita menopause. Kegiatan ini dilaksanakan dalam empat kali pelatihan yaitu pelatihan 1 materi tentang kader bagi wanita menopause, menopause. Pelatihan 2 materi tentang konsep dasar gizi, gizi masa menopause. Pelatihan 3 tentang ketrampilan pembuatan bobok jahe kunyit (bojanyit) untuk mengurangi keluhan arthritis. Pelatihan 4 tentang pemanfaatan kain perca dan bekas gelas teh menjadi barang yang bernilai ekonomi. Harapan dari kegiatan ini adalah adanya pendampingan dari UMKM Kabupaten Kediri untuk memberikan pelatihan yang bervariasi.
\end{abstract}

Kata kunci: kader ; pelatihan ; program KUWAT

\begin{abstract}
[MENOPAUSE ACTIVE WOMEN'S COLLECTION PROGRAM BY CADRES IN THE VILLAGE OF SUMBERBENDO PARE SUB DISTRICT] Health cadres are an extension of midwives who work as movers, motivators and providers of information to the community, including in improving the quality of life of menopausal women. In the village of Sumberbendo, Pare Subdistrict, Kediri Regency, the role of cadres cannot be maximally implemented, this is because cadres have never received training on the role of cadres and also information about menopause. In order to fulfill one of the universities for community service, the lecturer needs to improve the quality of life of menopausal women. One effort that can be done is to move the cadre so that they are able to run the Active Menopause Women (KUWAT) program that can be applied to menopausal women. This activity was carried out in four training sessions namely training 1 about cadres for menopausal women, menopause. Training 2 about the basic concepts of nutrition and nutrition during menopause. Training 3 on the skills of making bojanyit to reduce arthritis complaints. Training 4 on the use of patchwork and used glass teas into items of economic value. The expectation of this activity is the existence of assistance from the UMKM Kediri Regency to provide a variety of training.
\end{abstract}

Keywords: cadres ; training ; KUWAT program

\section{Pendahuluan}

Menopause adalah kondisi ketika masa menstruasi seorang wanita berakhir karena

*) Correspondence Author (Reni Yuli Astutik)

E-mail: reniyuliastutik@ymail.com ovarium berhenti memproduksi estrogen dan progesteron (Gibbs RS, et.al, 2008). Penurunan kadar hormon tersebut menyebabkan wanita mengalami gejala menopause yang dapat menurunkan kualitas hidup. Masa menopause 
rata-rata terjadi pada umur 45-55 tahun (Spencer F\&Brown P, 2007). Faktor-faktor seperti usia, tingkat pendidikan, pekerjaan signifikan mempengaruhi kualitas hidup wanita menopause. Pada wanita yang bekerja cenderung kualitas hidupnya lebih baik dibanding dengan wanita yang tidak bekerja. (Krajewska, K, et al 2007; Yun, BH, et.al, 2016). Penelitian yang serupa menyatakan terdapat hubungan yang signifikan antara status pekerjaan dengan kualitas hidup (Liu, K, et. al, 2014).

Berdasarkan studi di desa Sumberbendo, jumlah wanita menopause sebanyak $30 \%$ dari jumlah penduduk dengan mata pencaharian sebagai petani sejumlah $10 \%$ memiliki usaha (berjualan nasi ataupun toko kelontong) sejumlah $30 \%$ dan $60 \%$ sebagai ibu rumah tangga. Latar belakang pendidikan wanita menopause yaitu 25\% sekolah menengah, $60 \%$ sekolah dasar dan 15\% tidak tamat sekolah. Berdasarkan data kunjungan wanita menopause ke Puskesmas Bendo pada bulan Januari-September 2018 didapatkan sejumlah $79 \%$ dengan keluhan sakit pada persendian atau arthritis yang mengindikasikan adanya pola kansumsi yang kurang tepat. Sehingga perlu adanya upaya untuk menangani masalah yang ditimbulkan pada masa menopause agar dapat menumbuhkan rasa percaya diri, memberikan ketenangan batin, perasaan senang, aman, dan nyaman salah satunya dengan meningkatkan kualitas hidup dan kemandirian wanita menopause secara ekonomi melalui peran kader kesehatan. Kader kesehatan merupakan perpanjangan tangan dari bidan yang berfungsi sebagai penggerak, motivator serta pemberi informasi kepada masyarakat, termasuk dalam peningkatan kualitas hidup wanita menopause.

Dari hasil pengkajian pada kader desa Sumberbendo, didapatkan data bahwa kader belum melakukan peran secara maksimal dikarenakan belum pernah pelatihan tentang peran kader serta kurangnya informasi tentang menopause. Selain itu, meskipun sudah ada kader kesehatan yang menangani posyandu lansia, namun konsentrasi pada masalah yang dialami wanita menopause belum dapat ditangani.

Idealnya kader kesehatan bisa memberikan solusi terkait keluhan yang dirasakan oleh wanita menopause misalnya dengan memanfaatkan tanaman obat keluarga yaitu dengan menggunakan jahe dan kunyit baik dalam bentuk oles ataupun diminum sehingga meminimalkan wanita menopause untuk mengkonsumsi obat yang mengandung bahan kimia. Selain itu kader kesehatan juga perlu diberikan pelatihan terkait zat gizi bagi wanita menopause sehingga bisa memberikan informasi yang benar pada wanita menopause terkait gizi yang diperlukan. Kader kesehatan dilatih dan berfungsi sebagai monitor, pengingat dan pendukung untuk mempromosikan kesehatan (Astutik, 2019).

Berdasarkan permasalahan tersebut, maka dosen yang mempunyai kewajiban menjalankan Tridharma perguruan tinggi yang salah satunya adalah pengabdian kepada masyarakat merasa perlu untuk berperan dalam meningkatkan kualitas hidup wanita menopause. Salah satu upaya yang dapat dilakukan yaitu dengan menggerakkan kader posyandu sehingga mampu menjalankan program Kumpulan Wanita Menopause Aktif (KUWAT) yang dapat diterapkan pada wanita menopause.

\section{Metode}

Program Kemitraan Masyarakat (PKM) ini dilakukan pada kader desa Sumberbendo, Kecamatan Pare, Kabupaten Kediri Propinsi Jawa Timur yang berjumlah 20 orang pada bulan April sampai dengan Juli 2019. Lokasi pelaksanaan PKM di balai desa Sumberbendo. Metode yang dilakukan pada PKM dapat dilihat pada gambar 1.

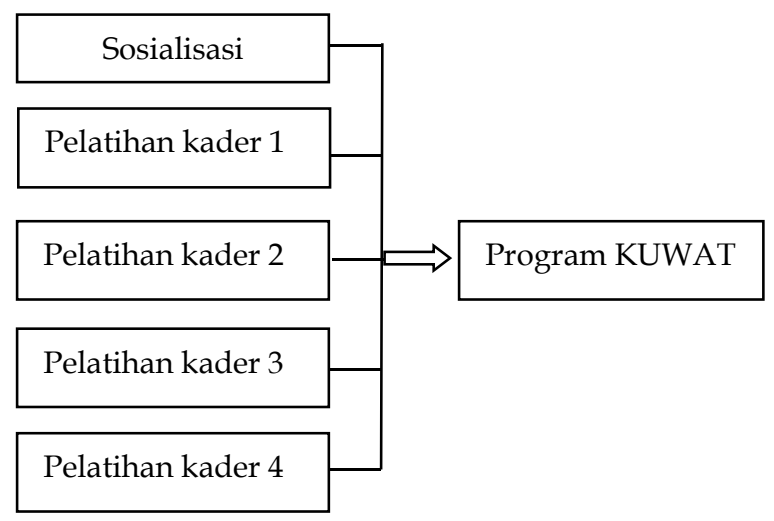

Gambar 1. Metode Pelaksanaan PkM

Alat yang digunakan untuk sosialisasi dan pelatihan kader 1 dan 2 meliputi LCD, laptop, pointer, mikrofon. Alat dan bahan untuk pelatihan kader 3 meliputi kompor listrik, gelas, blender, jahe, kunyit dan air. Alat dan bahan untuk pelatihan kader 3 meliputi mesin jahit 
listrik, kain perca, mainan ditempel, benang, resleuting untuk membuat ketrampilan dari kain perca yang berbentuk tempat tissue serta tempat jarum pentul. Sedangkan alat dan bahan untuk ketrampilan dari gelas bekas teh diperlukan cutter/pisau tajam, gunting, benang knoor, pita, boneka mainan tempel, bekas gelas teh yang nantinya dibentuk keranjang belanja, tas kondangan, tempat air minum. Penilaian keberhasilan salah satunya dilihat dari jumlah peserta yang hadir, kemampuan peserta mengikuti pelatihan dan mengerjakan tugas yang ada dalam modul pelatihan.

\section{Hasil dan Pembahasan}

PKM program KUWAT oleh kader desa Sumberbendo meliputi:

1) Sosialisasi Program KUWAT oleh tim pelaksana PKM kepada bidan desa dan kader.

Materi yang diberikan pada saat sosialisasi meliputi:

a. Maksud dan tujuan dilakukannya PkM program KUWAT bagi kader desa Sumberbendo.

b. Waktu pelaksanaan dan kegiatan yang dilakukan.

2) Pelatihan Kader 1, dengan pembicara adalah bidan.

a. Materi pertama tentang kader kesehatan bagi wanita menopause yang meliputi:
a) Pengertian kader
b) Tujuan pembentukan kader
c) Kriteria menjadi kader
d) Peran kader

b. Materi kedua tentang menopause yang meliputi:

a) Pengertian masa menopause

b) Batasan usia menopause

c) Faktor penyebab terjadinya menopause

d) Perubahan fisik masa menopause

e) Perubahan psikologis masa menopause

f) Keluhan masa menopause

g) Senam menopause

3) Pelatihan kader 2 dengan pembicara adalah ahli gizi.

a. Materi pertama tentang konsep gizi yang meliputi:

a) Prinsip ilmu gizi

b) Sejarah perkembangan ilmu gizi

c) Makanan dan gizi, klasifikasi zat gizi pedoman menu seimbang

b. Materi kedua tentang gizi masa menopause yang meliputi:

a) Prinsip gizi masa menopause

b) Makanan pada masa menopause

c) Hal-hal yang perlu diperhatikan masa menopause.

4) Pelatihan kader 3 diberikan oleh tim pengabdi. Materi yang diberikan adalah:

a. Jahe

b. Kunyit

c. Pembuatan bobok jahe kunyit (bojanyit)

5) Pelatihan Kader 4: transfer ketrampilan pemanfaatan barang dan bahan bekas. Narasumber berasal dari tim UMKM Kabupaten Kediri. Ketrampilan yang diajarkan meliputi:

a. Membuat tempat jarum pentul dan tempat tissue yang berasal dari kain perca.

b. Membuat keranjang belanja, tas kondangan serta tempat air minum dari bekas gelas teh.

Tingkat kehadiran kader $90 \%$ pada saat sosialisasi dan saat pelatihan $100 \%$. Kader dapat mengikuti pelatihan dan mempraktekkan ketrampilan yang diajarkan oleh narasumber. Kader dapat mengerjakan tugas/latihan secara mandiri dengan menjawab pertanyaan yang ada di dalam modul pelatihan program KUWAT. Kader juga dapat bermain peran/role play secara berkelompok saat pelatihan kader 1 dan 2 . Hal ini sebagai bukti bahwa kader adalah anggota masyarakat yang dipilih dari dan oleh masyarakat, mau dan mampu bekerja bersama dalam berbagai kegiatan kemasyarakatan secara sukarela (Kementerian Kesehatan Republik Indonesia, 2017).

Ketrampilan yang diajarkan kepada kader adalah membuat bobok jahe kunyit (bojanyit), Jahe mengandung gingerol yang memiliki sifat sebagai anti inflamasi. Gingerol inilah yang meringankan gejala nyeri pada persendian osteoarthritis dan rematik. Selain itu, jahe juga menghambat komponen yang berperan dalam proses inflamatori dalam tubuh seperti sitokin, kemokin, kondrosit, dan leukosit (Bachtiar, A. 2010). Senyawa gingerol, shogaol, dan substansi yang terkait secara struktural lainnya yang terdapat dalam jahe menghambat biosintesis prostaglandin dan leukotrin senyawa ini juga menghambat sintesis pro-antinflamasi sitokinin seperti IL-1, TNF-alpha, dan IL-Beta (Fitria, N dkk, 2016). 


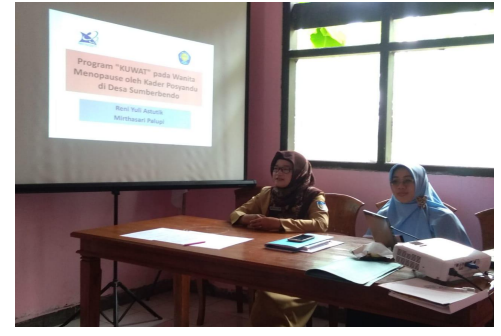

Gambar 2. Sosialisasi PkM program KUWAT

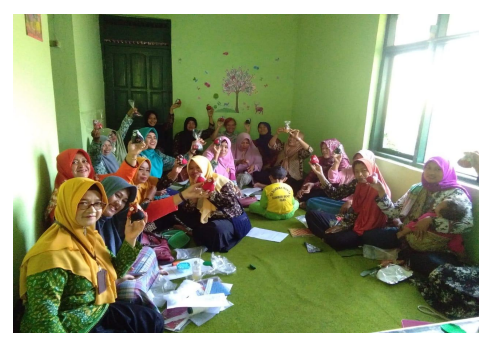

Gambar 3. Hasil ketrampilan dari kain perca

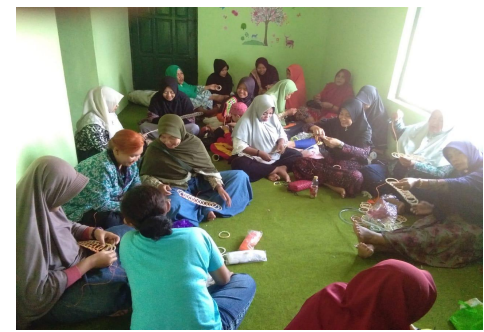

Gambar 4. Ketrampilan dari bekas gelas teh

$\begin{array}{rrrr}\text { Kunyit } & \text { terdiri dari tiga kelompok } \\ \text { curcuminoid } & \text { yaitu } & \text { curcumin } & \text { atau }\end{array}$ diferuloylmethylmethane, demethoxycurcum dan bichemethoxycurcumin. Curcumin merupakan komponen dalam kunyit yang berfungsi sebagai anti inflamasi serta sebagai antioksidan. Molekul antioksidan dalam tubuh melawan radikal bebas yang merusak membran sel tubuh, dan dapat menyebabkan kematian sel. Selain itu curcumin menghambat ekspresi COX-2 (Jurenka, 2009). Curcumin diakibatkan memiliki kemampuan dalam menghambat inhibisi COX-2, lipoxygenase (LOX), serta iNOS. Ketiga zat ini merupakan enzim yang memidiasi proses inflamasi (Fitria, N $\mathrm{dkk}, 2016)$. Selain itu, curcumin juga mengurangi kadar tiga enzim dalam tubuh yang menyebabkan inflamasi (Jurenka, 2009).

Ketrampilan lain yang diajarkan kepada kader dalam kegiatan PKM ini adalah memanfaatkan barang bekas untuk dijadikan barang yang bermanfaat dan memiliki nilai ekonomis. Sebagaimana disebutkan dalam UU RI No. 18 Tahun 2008, bahwa permasalahan sampah mencakup banyak aspek, oleh karena itu pengelolaannya perlu dilakukan secara komprehensif dan terintegrasi dengan inovasi-inovasi baru yang lebih memadai ditinjau dari segala aspek, baik itu aspek sosial, aspek ekonomi maupun aspek teknis dari hulu sampai ke hilir agar memberikan manfaat secara ekonomi, sehat bagi lingkungan, serta dapat mengubah perilaku masyarakat, artinya penanganan sampah perlu dilakukan sejak dari sumbernya. Hal ini mendasari adanya perubahan paradigma dalam pengelolaan sampah diantaranya dengan penerapan $3 R$ (reduse, reuse, recycle) (Puspitawati, Y \& Rahdriawan, M, 2012). Pemanfaatan kain perca yang dibuat kerajinan tangan dalam bentuk tempat tissue ataupun tempat jarum pentul serta bekas gelas teh yang dimanfaatkan untuk tas belanja, tas kondangan serta tempat air minum merupakan aplikasi dari recycle.

\section{Simpulan dan saran}

Dari kegiatan PKM ini, kader sudah memiliki pengetahuan terkait peran kader, menopause, keluhan dan penanganan keluhan masa menopsuse, konsep dasar gizi serta gizi bagi wanita menopause. Selain itu, kader juga memiliki ketrampilan memanfaatkan barang dan bahan bekas sehingga memiliki nilai ekonomi yang dapat diajarkan kepada wanita menopause.

Perlu adanya pendampingan kader dari UMKM Kabupaten Kediri dengan memberikan pelatihan pemanfaatan kain perca dan bekas gelas teh menjadi bentuk kerajinan yang lebih bervariasi.

\section{Ucapan Terima Kasih}

Terima kasih kami sampaikan kepada Ristekdikti yang telah mendanai program PKM ini.

\section{Daftar Pustaka}

Astutik, RY, Palupi, M. (2019). Modul Pelatihan: Program KUWAT bagi Wanita Menopause oleh Kader Posyandu. Jember: Pustaka Abadi

Bachtiar, A. 2010. Pengaruh Ekstrak Jahe (Zingiber officinale) Terhadap Tanda dan Gejala Osteoarthritis pada Pasien Rawat Jalan di Puskesmas Pandanwangi Kota Malang. Unpublished undergraduate thesis. Fakultas Ilmu Keperawatan Universitas 
Indonesia, Jakarta

Fitria, N, Hasballah, K, Mutiawati, E. (2016). Pemberian Campuran Kunyit dan Jahe dengan Tingkat Nyeri Pada Pasien Fraktur. Jurnal Ilmu Keperawatan, 4(1):17-24

Gibbs, RS, et.al. (2008). Danforth's Obstetrics and Gynecology, Edisi ke-10. Lippincott Williams \& Wilkins.

Jurenka, J. S. (2009). Anti-inflammmatory Properties of Curcumin, a Major Contituent of Curcuma Longa: A Review of Preclinical and Clinical Research. Alternative Medicine Review.

Kementerian Kesehatan Republik Indonesia. 2017. Pedoman Penyelenggaraan Posyandu. Jakarta: Kemenkes RI.

Krajewska, K. et.al. (2007) A. Comparative Analysis of Quality of Life Women in Menopause Period in Poland, Greece and Belorussia using MRS. Preliminary Report. Adv Med Sci, 52(1), 140-3

Liu, K, Liu H, Xun T, Jinwei W, et. al. (2014). Relationship Between menopause and healthrelated quality of life in middleaged Chinese women: a crosssectional study. BMC Women's Health, 14(7).

Spencer F, Brown P. (2007). Simple Guide Menopause. Jakarta: Erlangga

UU RI No. 18 Tahun 2008 tentang Pengelolaan Sampah.

Puspitawati, Y, Rahdriawan, M. (2012). Kajian Pengelolaan Sampah Berbasis Masyarakat dengan Konsep 3R (Reduce, Reuse, Recycle) di Kelurahan Larangan Kota Cirebon. Jurnal pembangunan Wilayah \& Kota. Biro Penerbit Planologi Undip, 8(4), 349-359.

Yun BH, Chon SJ, Choi YS, Cho S, Lee BS, Seo SK. (2016). The Effect of Prolonged Breastfeeding on The Development of Postmenopausal Osteoporosis in Population With Insufficient Calcium Intake and Vitamin D Level. Osteoporos Int. 27(9):2745-2753. 